\title{
New localities of Orobanche bartlingii Griseb. in the Silesian-Cracow Upland as a result of the spread of Libanotis pyrenaica (L.) Bourg. due to the changes in land use
}

\section{Beata Babczyńska-Sendek*, Agnieszka Błońska \& Izabela Skowronek}

Department of Botany and Nature Protection, Faculty of Biology and Environmental Protection, University of Silesia, Jagiellońska 28, 40-032 Katowice, Poland

* corresponding author (e-mail: beata.babczynska-sendek@us.edu.pl)

\begin{abstract}
Human activity is a factor strongly influencing the current state of vegetation. The abandonment of traditional land use enables uncontrolled secondary succession. Libanotis pyrenaica, a host plant for Orobanche bartlingii, is a great example of species that spread as a result of this process, especially in the area of the Silesian-Cracow Upland. The aim of this study is to show that the expansion of L. pyrenaica caused by changes in land use promotes spreading of $O$. bartlingii - a species rare in Poland and Europe. During the field research conducted in the last decade, further localities of $O$. bartlingii were found. The gathered data were summarized to supplement the known distribution of the species and to present floristic and ecological characteristics of the phytocenoses with the participation of L. pyrenaica and O. bartlingii.
\end{abstract}

Key words: Orobanche bartlingii spreading, Libanotis pyrenaica expansion, vegetation changes, the Cracow-Częstochowa Upland, the Silesian Upland

\section{Introduction}

Vegetation is a dynamic and constantly changing formation. Changes are connected both with natural factors, having no direct connection with human activity, as well as with anthropogenic factors of various kinds and diverse intensity.

Human activity has long been a factor strongly influencing vegetation. This human impact has led to creation of species-rich semi-natural communities which, for centuries, have been associated with relatively stable traditional methods of use. Large-scale changes in human activity, occurring in recent decades, in particular, the abandonment of traditional use of seminatural communities, enables the secondary succession process. This results in homogenization and trivialization of vegetation (Kornaś 1990).

In many regions of Poland, acceleration of the pace of landscape changes caused by changes in the land use has been observed approximately since 1990 . The area of arable land is decreasing and the area of fallow lands, extensive meadows, scrubs and forests is increasing (Solon 2003a). Acreage of rare plant communities, including semi-natural, associated with a specific way of use, is also shrinking (Solon 2003b). This causes changes in floras. Some species withdraw, becoming increasingly rare or they even disappear and others, particularly alien invasive and native expansive plants, spread.

The Silesian-Cracow Upland is a region where, in recent decades, changes in land use have taken place over a wide area and on a very large scale. People living in villages located near the Upper Silesian agglomeration and near numerous other urban-industrial centers have more possibilities of finding other ways to earn their living than agriculture. First of all, on a large-scale, farming has ceased on poor sandy soils and on skeletal soils (such soils have a large acreage in the Częstochowa Upland - mezoregion of the Cracow-Częstochowa Upland) as well as around large industrial facilities, 
especially Katowice Steelworks. The abandonment of mowing of large meadow areas and cessation of grasslands grazing occurred also at the same time.

The succession takes place on multiannual fallow lands and plant communities occurring nearby often influence floristic composition of developing vegetation (Babczyńska-Sendek et al. 2012). Fallow lands are occupied by certain plant species. Most often, it is Solidago canadensis L. but in dry and moderately dry soils, rendzinas or pararendzinas type, Libanotis pyrenaica (L.) Bourg. has increased the area of its occurrence. Moreover, this species sometimes spreads out over various other wastelands with soil rich in calcium carbonate.

Qualitative and quantitative changes in the floristic composition have been occurring in ungrazed xerothermic grasslands. Some plant species disappear or decrease their share, while others spread, often behaving like expansive plants. One of these species, which significantly increased its share in grasslands, especially in the Cracow-Częstochowa Upland, is L. pyrenaica.

L. pyrenaica is a host plant for Orobanche bartlingii Griseb. - a broomrape species rare in Poland. In Poland $O$. bartlingii is known from several localities (Piwowarczyk et al. 2009; Piwowarczyk 2012a), where it usually grew in xerothermic grasslands, thermophilous edge communities and, less frequently, on fallow lands. In recent years, in the Silesian Upland and the Częstochowa Upland, new, sometimes numerous localities of $O$. bartlingii were found in places where, during earlier investigations (Babczyńska 1978; BabczyńskaSendek 1984, 2005), the species was not observed.

The aim of this study is: to show that the expansion of $L$. pyrenaica caused by changes in land use promotes spreading of $O$. bartlingii, to supplement the map of $O$. bartlingii distribution in the Silesian-Cracow Upland area and to show floristic as well as ecological diversity of plant communities involving this species.

\section{Material and methods}

The basis of this study was a comparison of old data (Babczyńska 1978; Babczyńska-Sendek 1984, 2005) with recent figures. Part of $O$. bartlingii localities were found during other field investigations. Literature data (Brzeg \& Wika 2014), not included by Piwowarczyk (2012a), were also used. In addition, places of numerous occurrence of $L$. pyrenaica were surveyed. In localities where $O$. bartlingii was found or its presence was confirmed, the size of population was estimated and phytosociological relevés were made in plant communities with this species participation.

The occurrence of $O$. bartlingii in the Silesian-Cracow Upland is presented in cartograms ( $2 \times 2 \mathrm{~km}$ grid $)$ according to the methods set up for the "Distribution
Atlas of Vascular Plants in Poland" (ATPOL) (Zając 1978a, 1978b). Localities published by Piwowarczyk et al. (2009) and Piwowarczyk (2012a) as well as localities not included in these studies (authors' position and the position from the publication of Brzeg \& Wika 2014) were marked accordingly.

Phytosociological relevés were set together and classified using the TWINSPAN program. The analysis of ecological requirements (moisture, $\mathrm{pH}$ and soil fertility) of vascular plant species which was made using Ellenberg indicators values (Ellenberg \& Leuschner 2010) allowed us to compare the distinguished groups of communities. Ecological differences between them are shown in graphs made in the STATISTICA software (version 10). Names of vascular plants follow Mirek et al. (2002).

\section{Results}

\subsection{Libanotis pyrenaica spreading}

L. pyrenaica is a very common species on the Cracow-Częstochowa Upland (Urbisz 2004, 2012). In the past, it numerously occurred mainly in rock grasslands, especially in the area of larger and higher rock agglomerations. In early 1980s, patches of grassland communities with a large share of this species were very rare on slopes of hills or at their foots. They sporadically occupied a larger area and L. pyrenaica usually did not cover more than half of the vegetation patch. This type of phytocoenoses was found only at a few localities during the investigations carried out in years 1977-1982 on the grassland vegetation of the Częstochowa Upland (Babczyńska-Sendek 1984). After cessation of grazing, L. pyrenaica began to spread on slopes of hills, especially in places where it was present in rock grasslands (Fig. 1a-c). Today, in many places, its share in the plant cover is very large, thus in its flowering season, it often forms large white fields (Fig. 2). L. pyrenaica specimens occurring on slopes also spread into fallow lands situated at the foot of hills. Patches with its participation are sometimes very extensive.

In the Silesian Upland, L. pyrenaica occurs only in some areas of these mesoregions where geological base is built by Triassic limestone (Nowak 1999; BabczyńskaSendek 2005). Large patches of communities dominated by this species can be encountered in the Zabkowice Ridge (Garb Zabkowicki) - the central-eastern part of the Tarnowskie Góry Ridge (Garb Tarnogórski), in areas located southeast of Katowice Steelworks. It is a vast area in which the agricultural use of the land was abandoned after the construction of the steelworks. The old abandoned fields occupy many hectares there and they are separated only by roads and railway lines leading to the steelworks. L. pyrenaica occupied there fallow lands, ungrazed grasslands, escarpments of 


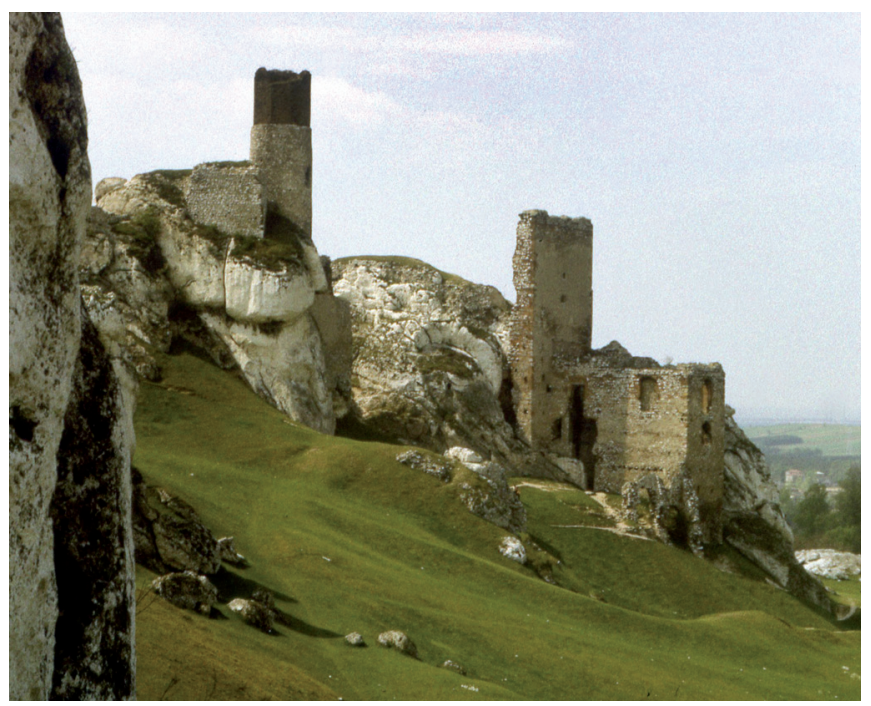

a

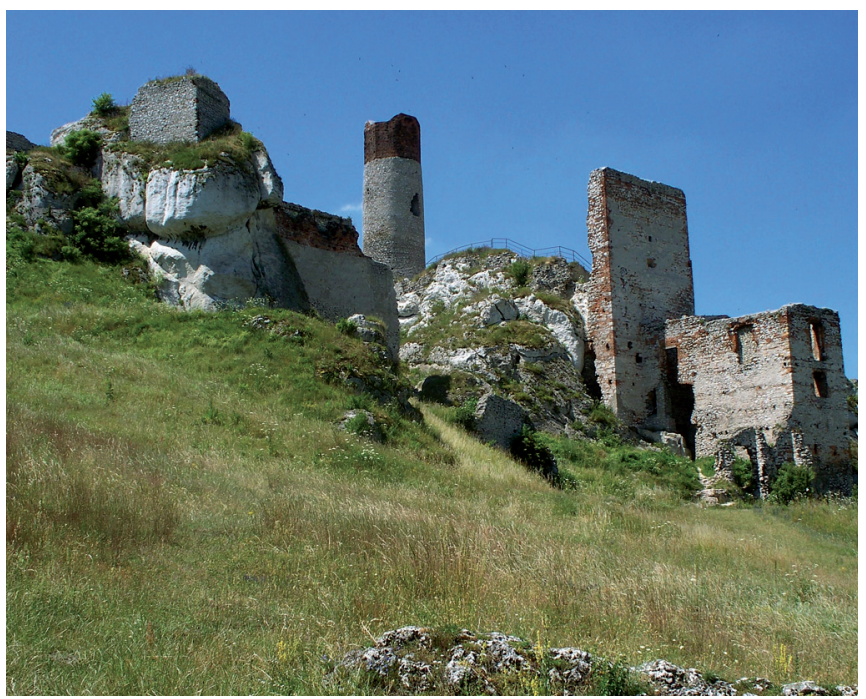

$\mathrm{b}$

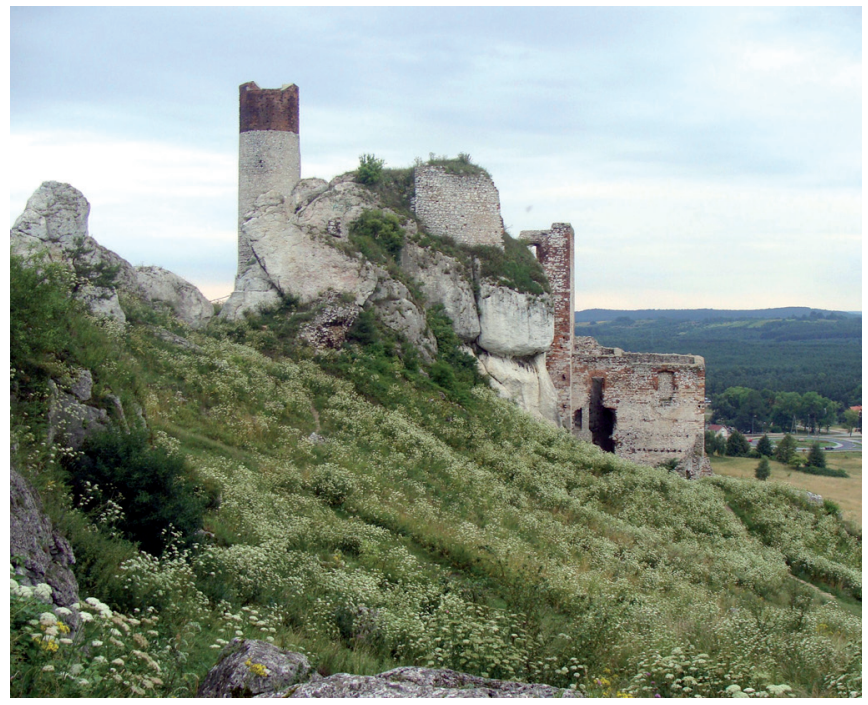

$\mathrm{C}$

Fig. 1. Changes in the vegetation of the Góra Zamkowa hill in Olsztyn near Częstochowa (Cracow-Częstochowa Upland)

Explanations: a - northern slopes of the Góra Zamkowa hill in 1987, b - the same slopes in 2008, c - extensive patches of the Libanotis pyrenaica community in 2011 (photograph by B. Babczyńska-Sendek)

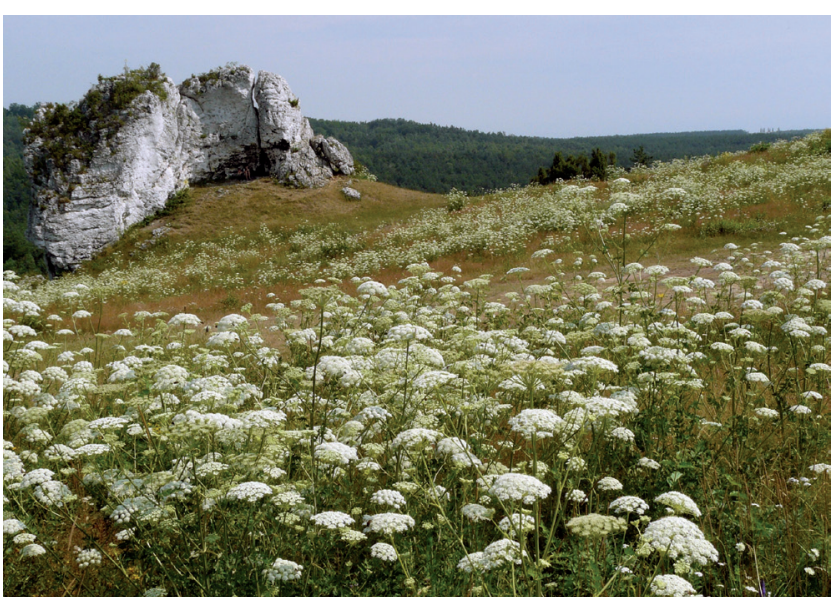

Fig. 2. White cover of Libanotis pyrenaica on the Mirów Ridge (Grzęda Mirowska) in the Cracow-Częstochowa Upland (photograph by M. Palowska, July 2010)

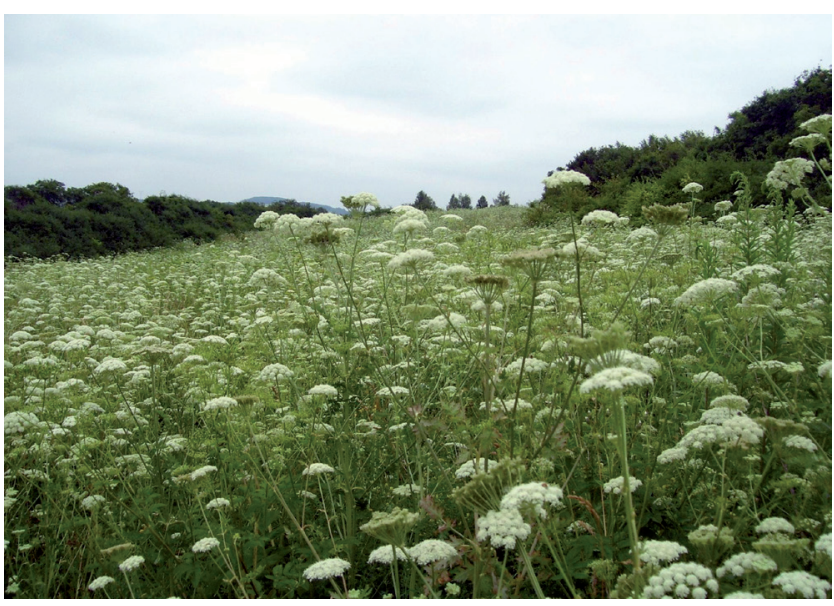

Fig. 3. Fallow land overgrown with Libanotis pyrenaica on the Twardowice Plateau, the Silesian Upland (photograph by J. Hejdysz, July 2009)

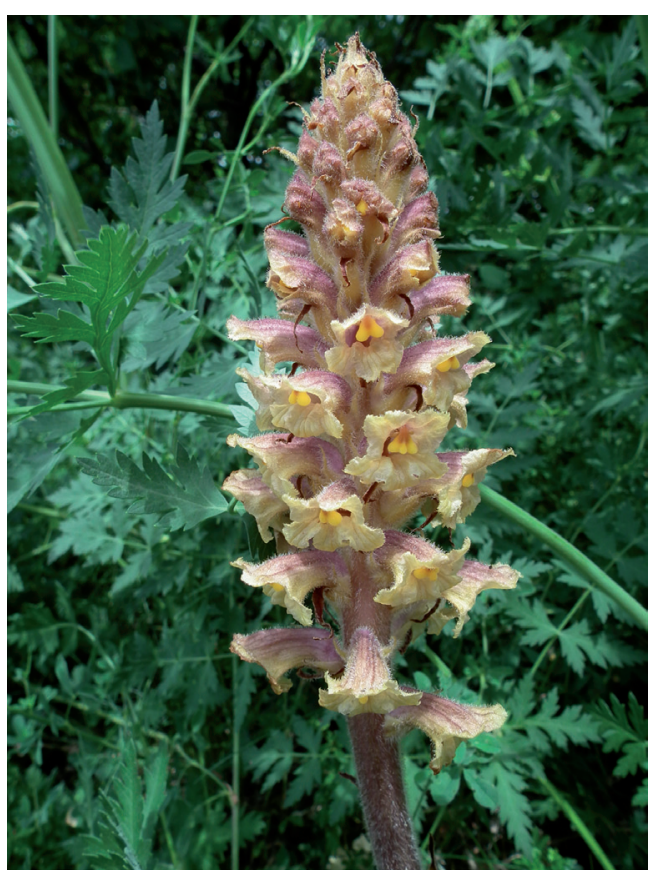

Fig. 4. Orobanche bartlingii Griseb. in Rzędkowice, the Cracow-Częstochowa Upland (photograph by B. Babczyńska-Sendek, June 2011) 
railway trenches, railway embankments and roadsides at the same time (Babczyńska-Sendek 2005). Lately, L. pyrenaica also spreads in the Ząbkowice Ridge area situated north of Katowice Steelworks and in the Twardowice Plateau (central part of the Tarnowskie Góry Ridge) where it colonizes, in particular, abandoned fields (Fig. 3) (Babczyńska-Sendek et al. 2012). In the Twardowice Plateau, its expansion into patches of xerothermic grasslands can also be observed in recent years.

\subsection{Orobance bartlingii spreading}

O. bartlingii (Fig. 4) is a broomrape species parasiting on L. pyrenaica (Kreutz 1995). In Poland, it was found for the first time in 1992 in the Ojców National Park (Szelag 2001). Then, the plant was found in other places in the Cracow-Częstochowa Upland such as: Rzędkowice in 1995 (Rakowski 2004), Podzamcze in 2003 (Babczyńska-Sendek unpublished data) and in 2007 (Piwowarczyk et al. 2009), Kobylańska Val- ley in 2005 (Nowak-Dańda \& Dańda 2006). In 2010, next three localities of $O$. bartlingii were found in the Ojców National Park area (Piwowarczyk 2011). Furthermore, this broomrape was also found in 1996 in the Silesian Upland area - on the Wielka Góra hill situated on the border of Strzemieszyce Małe and Sławków (Babczyńska-Sendek 2005, 2009) and in the northern part of Ząbkowice Ridge (the exact location not given) (Piwowarczyk 2012a).

In subsequent years, other localities of $O$. bartlingii were found in the Silesian Upland and the CracowCzęstochowa Upland (Fig. 5). In the area of the Silesian Upland, the extension of this species acreage was observed around the Wielka Góra hill - where the species was found for the first time in 1996. In years 2010 and 2011, on the border of Sławków and Okradzionów, $O$. bartlingii occurred frequently in several locations distant from the locality from 1996 approximately 1.5 to $2.5 \mathrm{~km}$, among others, in places where it was not noticed during the phytosociological survey carried out in 2001

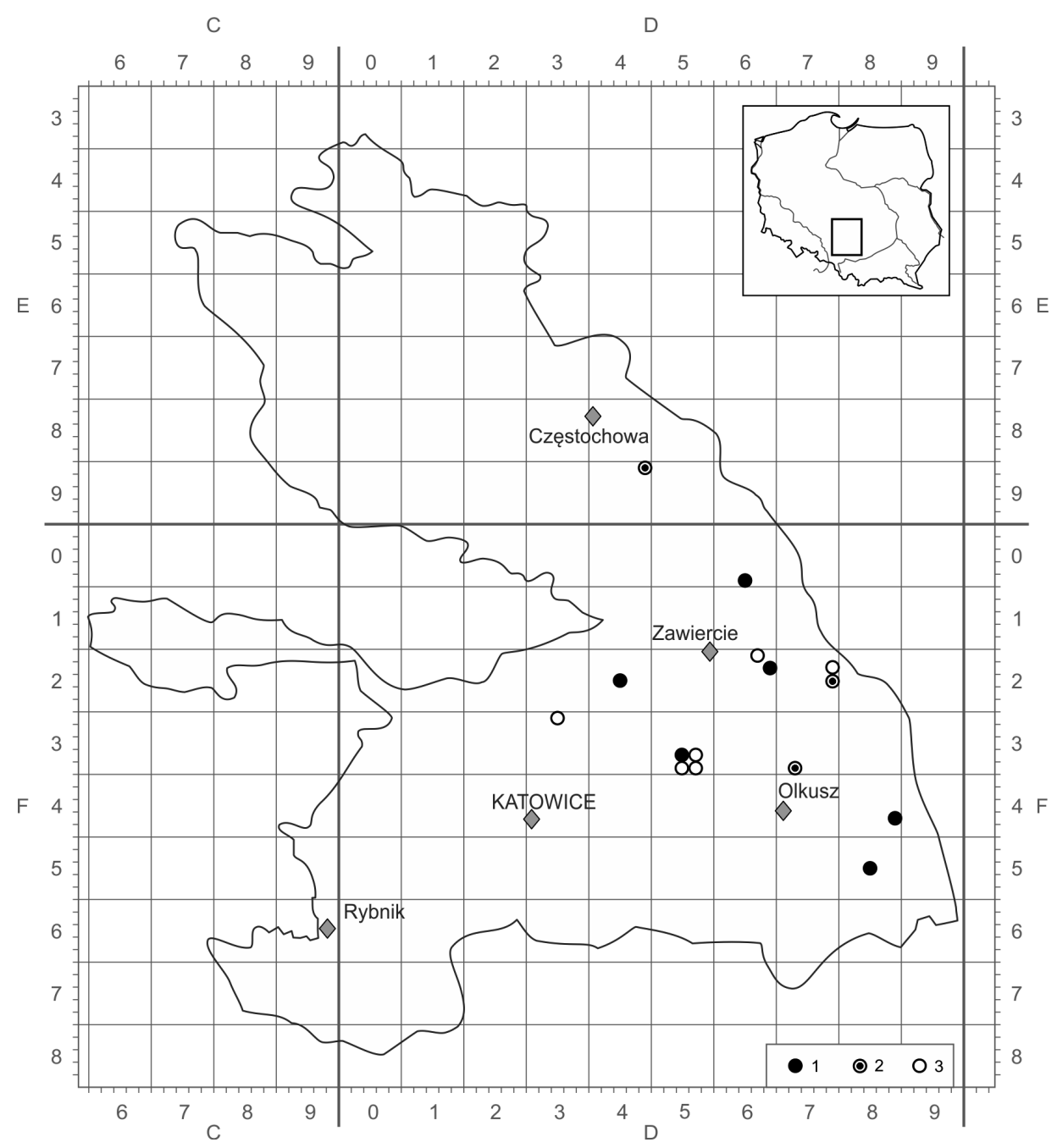

Fig. 5. Distribution of Orobanche bartlingii in the Silesian-Cracow Upland

Explanations: 1 - localities according to Piwowarczyk (2009, 2012a), 2 - localities according to Brzeg \& Wika (2014), 3 - new localities 
in patches of L. pyrenaica communities (BabczyńskaSendek 2005). Due to the fact that the area occupied by $L$. pyrenaica in this region is extremely large, it can be expected that after a detailed field research, the number of $O$. bartlingii localities may by higher there. Krajewski (2011) reported over a thousand flowering shoots of this species in the area of Dąbrowa Górnicza and Sławków. However, he did not specify accurate positions. In addition, $O$. bartlingii was found in 2009 in the area of Strzyżowice on the Twardowice Plateau (central part of the Tarnowskie Góry Ridge), where the species occurred both on fallow lands dominated by L. pyrenaica (Babczyńska-Sendek et al. 2012) and on the adjacent slope occupied by xerothermic grassland, in which L. pyrenaica started to occur.

New localities of the Bartling's broomrape were also found by the authors in the Cracow-Częstochowa Upland: in the vicinity of Bzów near Ogrodzieniec (in 2005) and in the Sikorowa Skała hill in Smolen (in 2012). O. bartlingii is also mentioned in recent phytosociological literature (Brzeg \& Wika 2014) - from the hill with castle ruins in Rabsztyn (2005), from the Pociejówka hill in Smoleń (2006), and from the Biakło hill in Olsztyn near Czestochowa (2007).

In Poland, in addition to the above-mentioned localities from the area of the Silesian-Cracow Upland, $O$. bartlingii is known only from two other stations: from the vicinity of New Stupia in the Kielce Upland and from the valley of the Noteć river (Piwowarczyk et al. 2009; Piwowarczyk 2012a, 2012b).

\subsection{The assessment of the Orobanche bartlingii population size in identified localities}

The number of $O$. individuals in the populations was very diverse in different stands. The most abundant were the populations from Rzędkowice and Podzamcze in the Częstochowa Upland area.

In Rzędkowice in 1995 and 1996, O. bartlingii grew at the eastern edge of the Rzędkowice Rocks (between the Turnia Lechwora and Turnia Kursantów peaks and near Okiennik rock), and its population consisted of dozens of individuals (Rakowski 2004). Then, Piwowarczyk et al. (2009) reported the existence of several thousand individuals in this area. During the conducted surveys in this location in 2007, the population was estimated at approximately 3000 individuals. It was also found that this species occurred in large numbers throughout almost the whole range of Rzędkowice Rocks, far more numerous in the upper part of the ridge and on southern slopes. It occurred also numerously on the northern slope, in its unwooded part. Moreover, $O$. bartlingii grew in large numbers at the foothills of southern slopes on fallow lands which were covered by L. pyrenaica. In 2010 and 2011, a slight extent of the area occupied by the broomrape on these fallow lands was observed. At the same time, the reduction of its population size was ascertained on the northern slope, where succession of trees and shrubs was taking place.

Piwowarczyk et al. (2009) wrote about the presence of $O$. bartlingii on the Góra Janowskiego hill in Podzamcze. The broomrape grew in dry grasslands near the outcrop of Jurassic rocks and the castle ruins, as well as on the edge of hazel shrubs, woods and paths. The population in 2007 was estimated at approximately 800 individuals. In contrast, observations made in 2008 showed that this population consisted of approximately 1500 individuals. The presence of this species was also reported in plantings of larch on the eastern slope which was still covered by numerous $L$. pyrenaica population. The species was present on fallow lands, at the foot of the eastern slope, which were covered by L. pyrenaica abundantly. In 2010, on these fallow lands, O. bartlingii individuals were found at a distance of $330 \mathrm{~m}$ from the foot of the slope. Unfortunately, in years 2009 and 2010 , due to the construction of a hotel in upper part of the western slope of the Gora Janowskiego hill, a large part of the population, occurring in grasslands on the top part of the hill, below the Czubatka rock and on the adjacent slope, was devastated.

However, two new populations of $O$. bartlingii from the area of the Cracow-Częstochowa Upland were far less numerous and occupied small areas. The population from Bzów in 2010 consisted of approximately 300 individuals and covered the surface of about $1000 \mathrm{~m}^{2}$. It was associated with a fragment of xerothermic grasslands in the upper part of the Jurassic cuesta slope in a close proximity to the old quarry. On the Sikorowa Skała hill, which was heavily overgrown with trees and shrubs, $O$. bartlingii grew in the fragment of xerothermic grassland with the presence of $L$. pyrenaica at the foot of the south-eastern part of the hill. Its population consisted of 32 individuals and occupied an area of approximately $100 \mathrm{~m}^{2}$.

Among the $O$. bartlingii localities listed in the study of Brzeg and Wika (2014) concerning thermophilous edge communities, only the ones placed on the Biakło hill in Olsztyn near Częstochowa were investigated (during another research in 2011-2014). Despite thorough exploration of the hill and other hills in the adjacent area, the broomrape was not found, while L. pyrenaica occurred abundantly on most of them. Probably in 2007, O. bartlingii appeared there sparsely (it was noted in two phytosociological relevés and its share was estimated at less than 1\%). Later, clearance of shrubs and undergrowth of pine trees on the hill was conducted. This action could have led to devastation of this sparse stand.

The size of $O$. bartlingii populations in the Silesian Upland also varied. The largest populations were found near the border of Strzemieszyce Małe, Okradzionów 
(the Dąbrowa Górnicza districts) and Sławków. When this species was found for the first time on the western edge of the Wielka Góra hill near Strzemieszyce, its population from the grasslands, overgrown with trees and bushes included several individuals. However, the entire hill which is extensive and mostly occupied by fallow lands, was not surveyed thoroughly. In contrast, the field survey carried out in 2010 showed that the population of $O$. bartlingii in the first-found locality comprised 22 specimens. Single individuals of the species were also encountered along the field path on the back of the Wielka Góra hill and on the northern slope of the neighboring hill - Góra Tomalówki.

Quite a large population (63 specimens) was also found southwest of the Wielka Góra hill (approximately $1.2 \mathrm{~km}$ ), on the verge of the road leading along the railway embankment. Another major group of specimens (252) was found on fallow fields overgrown by L. pyrenaica on both sides of the asphalt road leading from Strzemieszyce Małe to Okradzionów, about $2 \mathrm{~km}$ east of the Wielka Gora. Other localities of O. bartlingii were found in the distance of about $0.8 \mathrm{~km}$ at the edge of the same road (in a distance about $2 \mathrm{~km}$ in a straight line from the Wielka Góra) (68 individuals), on the verge of the road from Sławków to Okradzionów and on the nearby old fallow lands (about $2.2 \mathrm{~km}$ from the Wielka Gorra) - the localities consisted of a dozen individuals. As observed, $O$. bartlingii did not occur in places with very high density of $L$. pyrenaica basal leaves.
The population of $O$. bartlingii found in Strzyżowice was not very numerous. Despite the abundant appearance of $L$. pyrenaica on fallow lands, only about 30 individuals of the broomrape were found. Single specimens occurred in the xerothermic grassland on the adjacent slope.

\subsection{Plant communities with Orobanche bartlingii participation}

Phytosociological relevés made in phytocenoses of $L$. pyrenaica community with participation of $O$. bartlingii enabled us to present floristic and ecological characteristics of this community. Based on the results of the analysis carried out using the TWINSPAN program, three groups of phytocoenoses were identified (Appendix 1):

Group 1 (relevés 1-4) - phytocoenoses with the participation of $L$. pyrenaica from the central part of the Tarnowskie Góry Ridge (Twardowice Plateau). These were both phytocoenoses developed on abandoned fields as well as on the hill slope (xerothermic grassland) and at its foot on the side of the field path. They were characterized by the presence of some species, which were rather associated with the local species pool.

Group 2 (relevés 5-10) - most of them were phytocoenoses dominated by L. pyrenaica growing on abandoned fields which were not directly adjacent to the xerothermic grasslands. One relevé was from a roadside. In this group, there were both phytosociological relevés from the area of the Silesian Upland, as well as from

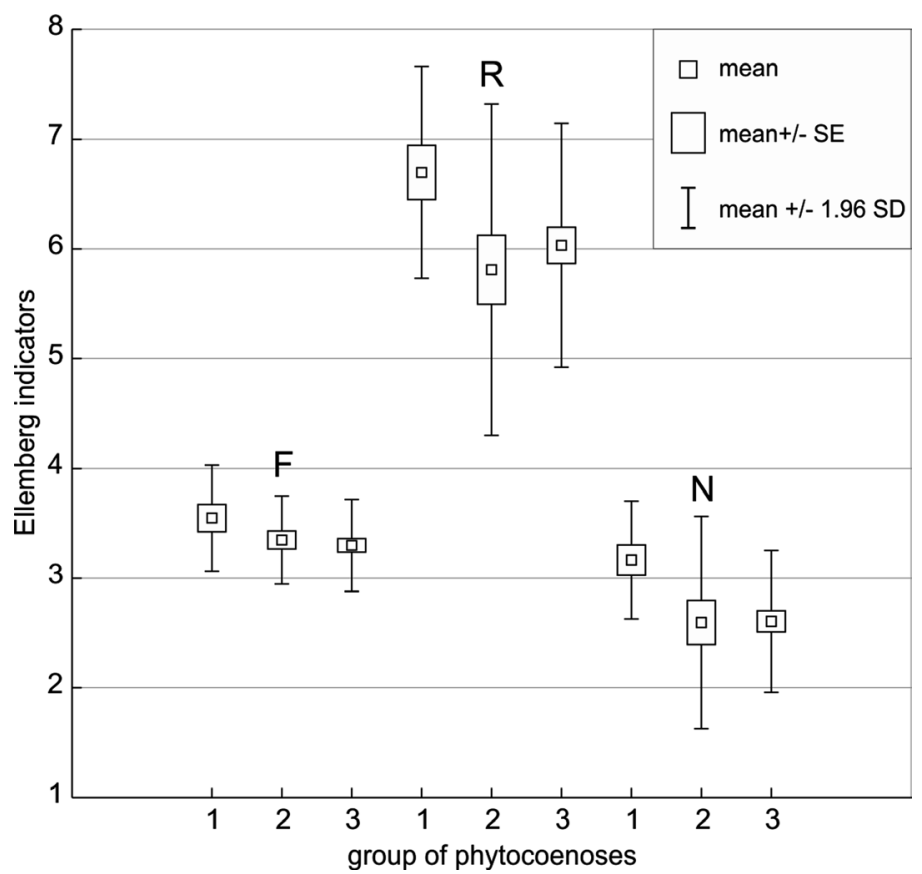

Fig. 6. Habitat characteristics of three distinguished groups of phytocoenoses with participation of Libanotis pyrenaica and Orobanche bartlingii using Ellenberg indicators

Explanations: $\mathrm{F}$ - moisture, $\mathrm{R}$ - reaction, $\mathrm{N}$ - nitrogen 
the Cracow-Częstochowa Upland. Plant species that prefer places with a slightly less dense plant cover, such as Arabis hirsuta, Artemisia campestris, Petrorhagia prolifera, were more frequent and more numerous there. This is due to the fact that the plant cover generally did not achieve full coverage in these patches.

Group 3 (relevés 11-22) - communities with dominance of $L$. pyrenaica from the area of the CracowCzęstochowa Upland, most of which developed on the site of xerothermic grasslands. This group also included three relevés from fallow lands which were situated at the foot of the hills in very close proximity to the slopes with grasslands. Patches included in this set were distinguished by a large group of species which were components of grassland phytocoenoses on slopes of hills.

Analysis of the habitat requirements of species forming particular phytocenoses showed that the distinguished groups differed from one another in terms of participation of plants with different moisture requirements and different preferences regarding soil fertility and $\mathrm{pH}$ (Fig. 6). Phytocoenoses from group 1 were distinguished most clearly. The ecological indicators of moisture, $\mathrm{pH}$ and fertility reached the highest mean values in this group. Phytocoenoses of all groups consisted mainly of species which prefer dryer habitats and grow on soils moderately acidic to slightly alkaline and poor or slightly rich in nitrogen.

\section{Discussion and conclusions}

Vegetation freed from under long-term anthropopressure is a more widespread phenomenon in contemporary landscape. Ex-agricultural lands (among others, old fields and pastures) abandoned for different reasons are a good example of "liberated" vegetation. Very often, changes do not lead to a return of primary vegetation. Then plant cover arising spontaneously as a result of different ecological processes and creation of a new pattern of communities can be observed (Faliński 2000). L. pyrenaica expansion, followed by O. bartlingii spreading, is an example of this type of changes in vegetation.

In literature, very little information about the increasing role of $L$. pyrenaica in grassland communities can be found. In Poland, the increasing share of this species has been found in phytocoenoses of OriganoBrachypodietum and Gymnocarpietum robertiani in the Pieniny National Park (Kaźmierczakowa \& Grodzińska 2006). Beyond Poland, the spread of L. pyrenaica was observed, e.g., in Bavaria (Nieschalk \& Nieschalk 1974) and Upper Normandy (Dutoit et al. 2003).

It is worth emphasizing that in the Silesian-Cracow Upland area, in most localities where L. pyrenaica occurs, very abundant populations are formed by this species and they cover vast surfaces. Explanation for this must be sought in the biology of this species, and, especially, in its fecundity and dispersal types.

L. pyrenaica does not have a high capacity to spread over long distances. Its seeds are heavy; based on different sources their weight is 1.12-2.51 (mean 2.01) mg (Jongejans \& Telenius 2001) or 1.3-1.7 (1.6) mg (Klotz et al. 2002). According to the criteria adopted by Kornaś (1972), species with such weight of seeds belong to heavy anemochorous (when their weight is less than $1.5 \mathrm{mg}$ ) or barochorous (when the weight exceeds $1.5 \mathrm{mg}$ ). Medwecka-Kornaś (1950), based on the average falling speed $\left(2.16 \mathrm{~m} \mathrm{~s}^{-1}\right)$ of seeds from the height of $5 \mathrm{~m}$, included L. pyrenaica in heavy anemochorous. Mean seed terminal velocity of $L$. pyrenaica is 2.90 $\mathrm{m} \mathrm{s}^{-1}$ (Jongejans \& Telenius 2001) and, according to Tackenberg et al. (2003), seeds that fall at $>2 \mathrm{~m} \mathrm{~s}^{-1}$ are very unlikely to be effectively dispersed by wind.

L. pyrenaica also belongs to boleochorous (Kleyer et al. 2008). Due to the fact that the stem with inflorescences grows up to $1.2 \mathrm{~m}$ (Koczwara 1960), seeds can be dispersed when the wind moves the stem. They will not be transferred to a long distance, but in relation to Jurassic hills, where L. pyrenaica grows on rocks often on hill tops, they can travel a considerable distance as a result of falling down the slope. Due to a large number of seeds produced usually per plant (an average of more than 13000 ) (Kleyer et al. 2008), the spreading of this species on slopes can be rapid and its extensive populations can occur there. A lack of intensive grazing is a necessary condition for this to happen. L. pyrenaica is usually a biennial plant, less frequently monocarpic-plurennial (Klotz et al. 2002), and when its inflorescences are eaten by animals, it is unable to produce seeds and, thus, the creation of the next generation.

Regarding the abundant occurrence of $L$. pyrenaica in some places of the Silesian Upland, an extension of its area is likely to happen in a different way. In the past, this species was not very common in the region (Schube 1903; Sendek 1984). In the Silesian Upland, there are no rock outcrops from which L. pyrenaica can spread in the Cracow-Częstochowa Upland. There is also little information about habitats which this species had occupied in the past. Among others, the following are mentioned: the castle walls and on the slope of the Wzgórze Zamkowe hill in Będzin (Celiński et al. 197475), outcrops of limestone in Strzyżowice (most likely, in the excavation of limestone, because there are no natural outcrops) (Celiński et al. 1978-79) and railway areas (Nowak 1997). The spread of this species over a large area is related to abandonment of agricultural land use, particularly in a large area around the Katowice Steelworks. Probably, in the first stage of the species spreading, epizoochory played a decisive role. Wild 
and farmed animals, especially sheep, can be dispersal vectors for L. pyrenaica (Kleyer et al. 2008). Its seeds can be dispersed by animals because of seed hairs which usually occur, although these hairs are not long. The experiment conducted by Fischer et al. (1996) showed that the effectiveness of that species spreading by sheep is substantial, despite a relatively short period of seed dispersal.

After the entering of L. pyrenaica into new outposts in the Silesian Upland area, the growth of population for a given locality was probably extensive. This process was undoubtedly strengthened by large seed production which is characteristic for this species (Kleyer et al. 2008). Moreover, the spread of the species was probably associated with geological aspects. In many places, the geological base built by Triassic limestone was uncovered during the laying of railway tracks to Katowice Steelworks, especially in places where the tracks were led in trenches. Their slopes are now overgrown with dense patches of $L$. pyrenaica at a distance of several kilometers. In addition, this area is poorly visited by people and sparsely populated undoubtedly favouring presence of wild animals there. Thus, epizoochory is certainly an important factor in the spread of this species. In addition, large areas of fallow lands on soils rich in calcium carbonate, and also quite fertile, create favourable conditions for the development of its numerous populations. As shown in France (Alard et al. 2005), soil of abandoned fields rich in $\mathrm{P}_{2} \mathrm{O}_{5}$ favors the development of $L$. pyrenaica.

Because of the life strategy (Grime 1979), L. pyrenaica is considered to be a representative of competitors. The share of plants of this group generally increases during the succession not only in grasslands (Moog et al. 2005; Dzwonko \& Loster 1998), but also in other types of habitats (Prévosto et al. 2011). Furthermore, features of $L$. pyrenaica such as heavy seeds, relatively late flowering time (July and August), a significant height of flowering specimens are characteristic for plants whose share increased in ungrazed grasslands (Moog et al. 2005; Peco et al. 2005; Castro et al. 2010).

$O$. bartlingii, as well as other species of the Orobanchaceae family, is a parasitic plant with tiny and light seeds (weight generally much less than $0.01 \mathrm{~g}$ ) which are dispersed by wind (Kreutz 1995). According to the division proposed by Kornaś (1972), it belongs to hovering anemochorous. Vittoz \& Engler (2007) classified it (together with Orchidaceae, ferns, Pyrola- ceae and trichometeorochory) to the self-proposed 5th dispersal type. It is a group of plants of which $99 \%$ diaspores is dispersed in open fields to a distance of 500 $\mathrm{m}$. In exceptionally favorable conditions, even greater dispersal distances cannot be ruled out. A large number of seeds (from 350 to over 9000) produced in one bag of Bartling's broomrape individual and great seed production per shoot $(1870-627250)$ are also features which promote efficient dissemination (Piwowarczyk \& Jankowska-Błaszczuk 2014). The seeds are very easily washed down into the deeper layers of the soil because of their very small size. To germinate, they must make contact with roots of the host plant. Germination is triggered by certain chemical signals released by roots of the host (Kreutz 1995).

A mass occurrence of L. pyrenaica, a host plant of $O$. bartlingii, in the Cracow-Częstochowa Upland and in some regions of the Silesian Upland is a factor which favours the spread of this broomrape in these areas. Large areas covered by patches of plant communities dominated by $L$. pyrenaica significantly increase the probability that seeds of Bartling's broomrape find a host.

A significant number of new localities of $O$. bartlingii recently found allowed us to conclude that, in the Cracow-Częstochowa Upland and in some places of the Silesian Upland, O. bartlingii is spreading into new localities. Moreover, it can be stated that the broomrape acreage around many existing positions is substantially increasing. Due to large areas covered by plant communities with a significant share of L. pyrenaica, further enlargement of $O$. bartlingii range in the SilesianCracow Upland can be expected in coming years.

However, continued existence and possible spreading of $O$. bartlingii to new localities, especially at the Cracow-Częstochowa Upland area, where attempts to restore grazing are being made now, will depend on the intensity of grazing. If it is intense enough, L. pyrenaica will be eliminated from grasslands on hill slopes. However, in the absence of grazing, slopes will be overgrown by bushes and $L$. pyrenaica will also be gradually eliminated, as it was observed in the Czyżówki rocky ridge in the Ojców National Park (Michalik 2009). It seems that moderate grazing may be most optimal, because this type of land use allows L. pyrenaica and $O$. bartlingii to exist in grasslands on hills slopes.

Acknowledgements. We are thankful to Grzegorz Schmidt for his kind help in improving the language in the manuscript. 


\section{References}

Alard D. Chabrerie O., Dutoit T., Roche P. \& Langlois E. 2005. Patterns of secondary succession in calcareous grasslands: can we distinguish the influence of former land uses from present vegetation data? Bas. App. Ecol. 6: 161-173.

BABCZYŃSKA B. 1978. Zbiorowiska murawowe okolic Olsztyna koło Częstochowy. Acta Biologica 5: 169-215.

BABCZyŃSKA-SENDEK B. 1984. Zbiorowiska łąkowe i murawowe Wyżyny Częstochowskiej. Ph. D. Thesis, Department of Geobotany and Nature Protection, University of Silesia, Katowice, Poland.

Babczyńska-SEndeK B. 2005. Problemy fitogeograficzne i syntaksonomiczne kserotermów Wyżyny Śląskiej. Prace Naukowe Uniwersytetu Śląskiego w Katowicach 2296: 1-237.

BABCZYŃSKA-SENDEK B. 2009. Significance of protection of the meadow and grassland communities for maintenance the floristic diversity in the area of the south-eastern Silesian Upland (Poland). Biodiv. Res. Conserv. 13: 49-60.

Babczyńska-Sendek B., BŁońska A. \& Hejdysz J. 2012. Characteristics of the flora of fallow lands on rendzina soils on the Twardowice Plateau (Silesian Upland). Acta Agrobotanica 65(4): 75-90.

Brzeg A. \& WiKa S. 2014. Termofilne ziołorośla okrajkowe z klasy Trifolio-Geranietea sanguinei Th. Müller 1962 na obszarze środkowej części Wyżyny Krakowsko-Częstochowskiej. 179 pp. Zespół Parków Krajobrazowych Województwa Śląskiego, Będzin.

Castro H., Lehsten V., Lavorel S. \& Freitas H. 2010. Functional response traits in relation to land use change in the Montado. Agriculture, Ecosystems and Environment 137: 183-191.

Celiński F., Ludera F., Rostański K., Sendek A. \& Wika S. 1974-75. Nowe stanowiska roślin naczyniowych na Górnym Śląsku i terenach przyległych. Cz. I, II. Opolskie Towarzystwo Przyjaciół Nauk. Zeszyty Przyrodnicze 14-15: 11-31.

Celiński F., Rostański K., Sendek A., Wika S. \& Cabala S. 1978-79. Nowe stanowiska rzadkich roślin na Górnym Śląsku i terenach przyległych. Cz. IV. Zesz. Przyr. OTPN 18: 3-18.

Dutoit T., Buisson E., Roche P. \& Alard D. 2003. Land use history and botanical changes in the calcareous hillsides of Upper-Normandy (north-western France): new implications for their conservation management. Biol. Conserv. 115: 1-19.

Dzwonko Z. \& Loster S. 1998. Ochrona półnaturalnych muraw nawapiennych we współczesnym krajobrazie: dynamika roślinności po wycięciu drzew. Ochr. Przyr. 55: 3-23.

Ellenberg H. \& Leuschner Ch. 2010. Vegetation Mitteleuropas mit den Alpen. 6. Auflage. 1334 pp. Verlag Eugen Ulmer, Stuttgart.

FALIŃSKI J. B. 2000. The interpretation of contemporary vegetation transformation on the basis of the theories of synanthropisation and syndynamics. In: B. JACKOWIAK \& W. ŻUKOWSKI (eds.). Mechanisms of
Anthropogenic Changes of the Plant Cover. Publications of the Department of Plant Taxonomy of the Adam Mickiewicz University in Poznań 10: 9-30. Bogucki Wyd. Nauk., Poznań.

Fischer S. F., Poschlod P. \& Beinlich B. 1996. Experimental studies on the dispersal of plants and animals on sheep in calcareous grasslands. J. App. Ecol. 33: 1206-1222.

Grime J. P. 1979. Plant Strategies and Vegetation Processes. 213 pp. J. Wiley \& Sons, Chichester.

Jongejans E. \& Telenius A. 2001. Field experiments on seed dispersal by wind in ten umbelliferous species (Apiaceae). Plant Ecol. 151: 67-78.

KaŹMiercZakowa R. \& GrodzińSKa K. 2006. Przemiany zbiorowisk naskalnych i kserotermicznych w Pienińskim Parku Narodowym w ostatnich 35 latach XX wieku. Studia Naturae 54(1): 85-132.

Kleyer M., Bekker R. M., Knevel I. C., Bakker J. P, Thompson K., Sonnenschein M., Poschlod P., Van Groenendael J. M., Klimeš L., Klimešová J., KlotZ S., Rusch G. M., Hermy M., Adriaens D., Boedeltue G., Bossuyt B., Dannemann A., Endels P., GötzenBerger L., Hodgson J.G., Jackel A-K., Kühn I., Kunzmann D., Ozinga W. A., Römermann C., Stadler M., Schlegelmilch J., Steendam H. J., Tackenberg O., Wilmann B., Cornelissen J. H. C., Eriksson O., Garnier E. \& Peco B. 2008. The LEDA Traitbase: A database of life-history traits of Northwest European flora. Journal of Ecology 96: 1266-1274.

Klotz S., Kühn I. \& Durka W. (eds.). 2002. BIOLFLOR - Eine Datenbank zu biologisch-ökologischen Merkmalen der Gefäßpflanzen in Deutschland. Schriftenreihe für Vegetationskunde 38. Bonn: Bundesamt für Naturschutz.

KoczWAra M. 1960. Rodzina: Umbelliferae, Baldaszkowate. In: B. PawŁowski \& A. JAsiewicz (eds.). Flora polska. Rośliny naczyniowe Polski i Ziem Ościennych, 9, 137 pp. Instytut Botaniki im. W. Szafera, PAN, Kraków.

KoRnAŚ J. 1972. Rozmieszczenie i ekologia rozsiewania się chwastów w zespołach polnych w Gorcach. Acta Agrobotanica 25(1): 1-66.

KoRnAŚ J. 1990. Jak i dlaczego giną zespoły roślinne? Wiad. Bot. 34(2): 7-16.

Krajewski Ł. 2011. Zaraza Bartlinga w Zagłębiu Dąbrowskim. Przyroda Górnego Śląska 68: 3.

Kreutz C. A. J. 1995. Orobanche. The European broomrape species. Central and northern Europe. 159 pp. Naturhistorisch Genootschap, Limburg.

Medwecka-Kornaś A. 1950. Biologia rozsiewania naskalnych zespołów roślinnych Jury Krakowskiej. Rozpr. Wydz. Mat.-Przyr. PAU, 74 Dz. B, 1: 1-41.

Michalik S. 2009. Zmiany liczebności i rozmieszczenia wybranych gatunków kserotermicznych i górskich na stałej powierzchni badawczej „Czyżówki” w latach 1988-2007. Prądnik 19: 243-256.

Mirek Z., PięKoŚ-Mirkowa H., ZająC A. \& ZająC M. 2002. Flowering plants and pteridophytes of Poland. A checklist. In: Z. MireK (ed.). Biodiversity of Poland, 
1, 442 pp. W. Szafer Institute of Botany, Polish Academy of Sciences, Kraków.

Moog D., Kahmen S. \& Poschold P. 2005. Application of CSR- and LHS-strategies for the distinction of differently managed grassland. Basic Appl. Ecol. 6: 133-143.

Nieschalk A. \& Nieschalk Ch. 1974. Mittelungen zur Verbreitung von Orobanche bartlingii Griseb. (=Orobanche libanotidis Ruprecht, O. alsatica Kirschleger var. libanotidis [Ruprecht] Beck) in Bayern. Ber. Bayer. Bot. Ges. 45:71-74.

NowAK T. 1997. Flora synantropijna linii kolejowej Dąbrowa Górnicza-Strzemieszyce - Olkusz. Acta Biol. Siles. 30(47): 86-105.

Nowak T. 1999. Atlas rozmieszczenia roślin naczyniowych na terenie wschodniej części Garbu Tarnogórskiego (Wyżyna Śląska). Materiały, Opracowania 2. Centrum Dziedzictwa Przyrody Górnego Śląska, Katowice.

NowAK-DańdA A. \& DAŃdA P. 2006. Nowe stanowisko Orobanche bartlingii w Polsce. Fragm. Flor. Geobot. Polonica 13(2): 409-432.

Peco B., de Pablos I., Traba J., \& Levassor C. 2005. The effect of grazing abandonment on species composition and functional traits: the case of dehesa grasslands. Bas. App. Ecol. 6: 175-183.

Piwowarczyk R. 2011. Nowe stanowisko Orobanche bartlingii Griseb. (Orobanchaceae) w Ojcowskim Parku Narodowym, pp. 75-76. In: Zróżnicowanie muraw kserotermicznych w Polsce. Ogólnopolska Konferencja Naukowa, Lublin.

PiwowARCZYK R. 2012a. Revised distribution and plant communities of Orobanche alsatica and notes on the Orobanchaceae series Alsaticae in Poland. Biodiv. Res. Conserv. 26: 39-51.

Piwowarczyk R. 2012b. The genus Orobanche L. (Orobanchaceae) in the Małopolska Upland (S Poland): distribution, habitat, host preferences, and taxonomic problems. Biodiv. Res. Conserv. 26: 3-22.

PiwowarczyK R. \& Jankowska-BŁaszczuk M. 2014. Interspecific diversity of seed productivity and morphological features in parasitic species Orobanche bartlingii Griseb. (Orobanchaceae). Pol. J. Ecol. 62: 701-716.

Piwowarczyk R., Nobis M. \& Przemyski A 2009. Orobanche bartlingii Griseb. (Orobanchaceae) in Poland: taxo- nomical position, distribution and habitat requirements. Biodiv. Res. Conserv. 13:3-8.

Prévosto B., Kuiters L., Bernhardt-Römermann M., Dölle M., Schmidt W., Hoffmann M., Van Uytvanck J., Bohner A., Kreiner D., Stadler J. \& Klotz S 2011. Impacts of land abandonment on vegetation: successional pathways in European habitats. Folia Geobot. 46: 303-325.

Rakowski W. 2004. A new locality of Orobanche bartlingii (Orobanchaceae) in Poland. Pol. Bot. Jour. 49(1): 103-108.

Schube T. 1903. Die Verbreitung der Gefäßpflanzen in Schlesien preußischen und österreichischen Anteils. IV+240 pp. Druck von R. Nischkowsky, Breslau.

SENDEK A. 1984. Rośliny naczyniowe Górnośląskiego Okręgu Przemysłowego. 137 pp. OTPN, PWN, Warszawa-Wrocław.

SolON J. 2003a. Różnorodność ponadgatunkowa-krajobrazy. In: R. ANDRzejewski R. \& A. Weigle (eds.). Różnorodność biologiczna Polski, pp. 155-159. Narodowa Fundacja Ochrony Środowiska.

Solon J. 2003b. Różnorodność ponadgatunkowa - zbiorowiska roślinne. In: R. ANDRZEJEWSKi \& A. WeIGLE (eds.). Różnorodność biologiczna Polski, pp. 139-154. Narodowa Fundacja Ochrony Środowiska.

Szeląg. Z. 2001. Orobanche bartlingii (Orobanchaceae), a species new to Poland. Pol. Bot. J. 46(1): 79-81.

Tackenberg O., Poschlod P. \& Bonn S. 2003. Assessment of wind dispersal potential in plant species. Ecological Monographs 73: 191-205.

UrBisz A. 2004. Konspekt flory roślin naczyniowych Wyżyny Krakowsko-Częstochowskiej. Prace Naukowe Uniwersytetu Śląskiego w Katowicach 2240: 1-285.

URBISZ A. 2012. Atlas rozmieszczenia roślin naczyniowych na Wyżynie Krakowsko-Częstochowskiej. 284 pp. Centrum Dziedzictwa Przyrody Górnego Śląska, Katowice.

Vittoz P. \& Engler R. 2007. Seed dispersal distances: a typology based on dispersal modes and plant traits. Bot. Helv. 117: 109-124.

ZAJAC A. 1978a. Atlas of distribution of vascular plants in Poland (ATPOL). Taxon 27(5-6): 481-484.

ZAJĄC A. 1978b. Założenia metodyczne „Atlasu rozmieszczenia roślin naczyniowych w Polsce". Wiad. Bot. 22(3):145-155. 
Appendix 1. Plant communities with Libanotis pyrenaica and Orobanche bartlingii

\begin{tabular}{|c|c|c|c|c|c|c|c|c|c|c|c|}
\hline Successive No. of relevé & & 1 & 2 & 3 & 4 & 5 & 6 & 7 & 8 & 9 & 10 \\
\hline Field No. of relevé & & 6 & 7 & 5 & 4 & 9 & 19 & 10 & 8 & 13 & 20 \\
\hline Locality & & $\mathrm{S}$ & $\mathrm{S}$ & S & $\mathrm{S}$ & $\mathrm{P}$ & St & $\mathrm{P}$ & $\mathrm{O}$ & $\mathrm{Rz}$ & $\mathrm{O}$ \\
\hline & & 12 & 12 & 12 & 12 & 2 & 4 & 2 & 2 & 27 & 4 \\
\hline Date & & 7 & 7 & 7 & 7 & 8 & 8 & 8 & 8 & 8 & 8 \\
\hline & & 10 & 10 & 10 & 10 & 10 & 11 & 10 & 10 & 10 & 11 \\
\hline Area of the relevé $\left(\mathrm{m}^{2}\right)$ & & 40 & 50 & 40 & 40 & 50 & 50 & 50 & 50 & 50 & 40 \\
\hline Exposure & & ENE & ESE & $\mathrm{N}$ & $\mathrm{E}$ & - & - & $\mathrm{S}$ & $\mathrm{N}$ & $\mathrm{S}$ & WSW \\
\hline Slope $^{\circ}$ & & 3 & 5 & 3 & 25 & - & - & 5 & 5 & 10 & 3 \\
\hline Density of b layer (\%) & & - & - & - & - & - & - & - & 5 & 20 & - \\
\hline Cover of c layer $(\%)$ & & 100 & 100 & 100 & 100 & 100 & 90 & 95 & 90 & 90 & 95 \\
\hline Cover of d layer $(\%)$ & & - & - & - & - & - & 30 & 5 & 5 & 20 & 10 \\
\hline Type of habitat & & $\mathrm{f}$ & $\mathrm{f}$ & $\mathrm{r}$ & $\mathrm{g}$ & $\mathrm{f}$ & $\mathrm{f}$ & $\mathrm{f}$ & $\mathrm{f}$ & $\mathrm{f}$ & $\mathrm{r}$ \\
\hline No. of species in the relevé & & 36 & 33 & 21 & 30 & 41 & 41 & 37 & 38 & 41 & 39 \\
\hline Group No. & & \multicolumn{4}{|c|}{1} & \multicolumn{6}{|c|}{2} \\
\hline *Libanotis pyrenaica & & 4 & 4 & 4 & 2 & 4 & 5 & 3 & 4 & 4 & 4 \\
\hline *Orobanche bartlingii & & 1 & + & + & + & 2 & + & 2 & 1 & 2 & 1 \\
\hline \multicolumn{12}{|l|}{ D. Groups: } \\
\hline *Ononis spinosa & & 2 & . & + & 2 & . & 1 & . & . & . & . \\
\hline *Brachypodium pinnatum & & . & . & 3 & 4 & . & . & . & . & . & . \\
\hline *Dianthus carthusianorum & & + & . & + & 2 & . & . & . & . & . & . \\
\hline${ }^{\circ}$ Vicia cracca & & 1 & 1 & + & + & . & . & . & . & . & . \\
\hline *Lathyrus tuberosus & & 3 & 1 & 2 & . & . & . & . & . & . & . \\
\hline${ }^{\circ}$ Galium verum & & 1 & . & 1 & + & . & . & . & . & . & . \\
\hline *Centaurea scabiosa & & + & + & + & \multicolumn{2}{|l|}{1} & + & 1 & 1 & 1 & + \\
\hline *Picris hieracioides & & 2 & 1 & + & . & . & + & . & 2 & + & 2 \\
\hline *Artemisia campestris & & . & . & . & . & + & + & + & . & 1 & + \\
\hline${ }^{\circ}$ Leontodon hispidus & & . & . & . & . & + & . & + & 3 & + & 2 \\
\hline *Petrorhagia prolifera & & . & . & . & . & . & + & + & + & . & + \\
\hline *Arabis hirsuta & & . & . & . & . & . & + & + & . & + & . \\
\hline - Plantago lanceolata & & . & . & + & . & 1 & + & 1 & + & + & + \\
\hline *Thymus pulegioides & & . & . & . & . & + & + & 3 & . & 3 & 2 \\
\hline *Scabiosa ochroleuca & & . & . & . & + & 1 & + & 2 & + & + & 1 \\
\hline *Veronica spicata & & . & . & . & . & 2 & . & + & . & + & . \\
\hline *Poa angustifolia & & . & . & + & . & + & + & . & + & . & 1 \\
\hline${ }^{\circ}$ Rumex acetosa & & . & . & . & . & + & . & + & . & + & . \\
\hline *Poa compressa & & . & . & . & . & . & + & . & + & . & 1 \\
\hline${ }^{\circ}$ Avenula pubescens & & . & . & . & . & + & + & + & . & . & + \\
\hline *Seseli annuum & & . & . & . & . & 2 & + & + & . & . & . \\
\hline *Silene nutans & & . & . & . & . & . & . & 2 & . & 2 & . \\
\hline *Anthyllis vulneraria & & . & . & . & . & . & + & . & 1 & . & + \\
\hline${ }^{\circ}$ Phleum pratense & & . & . & . & . & . & . & + & + & . & + \\
\hline *Agrimonia eupatoria & & . & . & . & . & + & . & . & . & + & . \\
\hline *Cerastium arvense & & . & . & . & . & . & . & $\mathrm{r}$ & . & + & . \\
\hline *Briza media & & . & . & . & 1 & . & . & . & . & . & . \\
\hline *Sanguisorba minor & & . & . & . & + & . & 1 & . & . & . & . \\
\hline *Silene vulgaris & & . & . & + & . & . & . & . & . & + & . \\
\hline *Prunus spinosa & $\mathrm{b} / \mathrm{c}$ & . & . & . & . & . & . & . & . & . & . \\
\hline *Agrostis capillaris & & . & . & . & . & . & . & . & . & . & . \\
\hline *Convolvulus arvensis & & . & . & . & . & . & . & + & . & . & . \\
\hline *Anthoxanthum odoratum & & . & . & . & . & . & . & . & . & . & + \\
\hline${ }^{\circ}$ Festuca pratensis & & . & . & . & . & . & . & . & . & . & . \\
\hline * Carex caryophyllea & & . & . & . & . & . & . & . & . & . & . \\
\hline
\end{tabular}




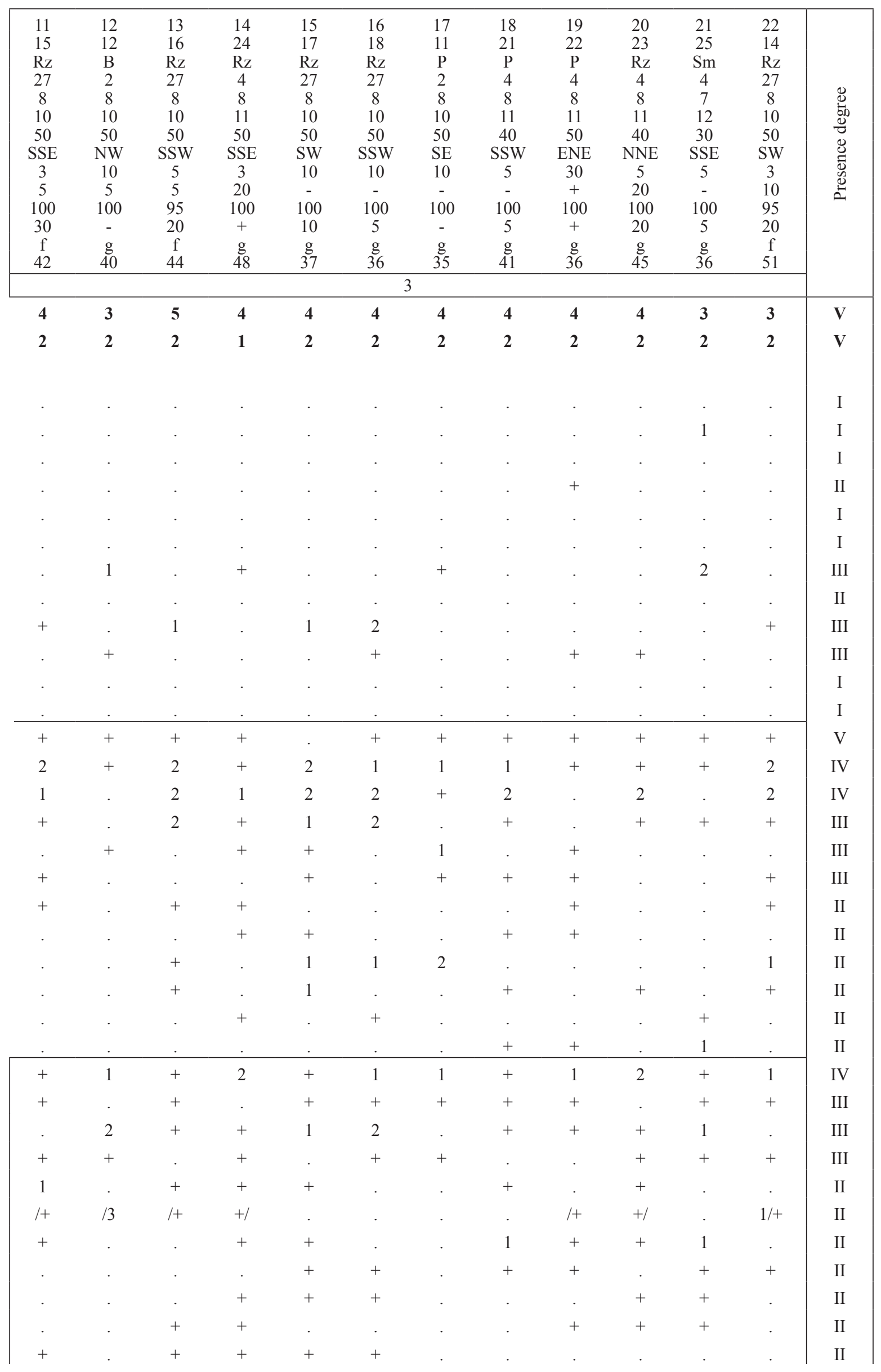




\begin{tabular}{|c|c|c|c|c|c|c|c|c|c|c|}
\hline Successive No. of relevé & 1 & 2 & 3 & 4 & 5 & 6 & 7 & 8 & 9 & 10 \\
\hline Field No. of relevé & 6 & 7 & 5 & 4 & 9 & 19 & 10 & 8 & 13 & 20 \\
\hline \multirow[t]{2}{*}{ Locality } & $\mathrm{S}$ & $\mathrm{S}$ & $\mathrm{S}$ & $\mathrm{S}$ & $\mathrm{P}$ & Sł & $\mathrm{P}$ & $\mathrm{O}$ & $\mathrm{Rz}$ & $\mathrm{O}$ \\
\hline & 12 & 12 & 12 & 12 & 2 & 4 & 2 & 2 & 27 & 4 \\
\hline \multirow[t]{2}{*}{ Date } & 7 & 7 & 7 & 7 & 8 & 8 & 8 & 8 & 8 & 8 \\
\hline & 10 & 10 & 10 & 10 & 10 & 11 & 10 & 10 & 10 & 11 \\
\hline Area of the relevé $\left(\mathrm{m}^{2}\right)$ & 40 & 50 & 40 & 40 & 50 & 50 & 50 & 50 & 50 & 40 \\
\hline Exposure & ENE & ESE & $\mathrm{N}$ & $\mathrm{E}$ & - & - & $\mathrm{S}$ & $\mathrm{N}$ & $\mathrm{S}$ & WSW \\
\hline Slope $^{\circ}$ & 3 & 5 & 3 & 25 & - & - & 5 & 5 & 10 & 3 \\
\hline Density of b layer (\%) & - & - & - & - & - & - & - & 5 & 20 & - \\
\hline Cover of c layer $(\%)$ & 100 & 100 & 100 & 100 & 100 & 90 & 95 & 90 & 90 & 95 \\
\hline Cover of d layer (\%) & - & - & - & - & - & 30 & 5 & 5 & 20 & 10 \\
\hline Type of habitat & $\mathrm{f}$ & $\mathrm{f}$ & $\mathrm{r}$ & $\mathrm{g}$ & $\mathrm{f}$ & $\mathrm{f}$ & $\mathrm{f}$ & $\mathrm{f}$ & $\mathrm{f}$ & $\mathrm{r}$ \\
\hline \multirow{2}{*}{$\begin{array}{l}\text { No. of species in the relevé } \\
\text { Group No. }\end{array}$} & 36 & 33 & 21 & 30 & 41 & 41 & 37 & 38 & 41 & 39 \\
\hline & \multicolumn{4}{|c|}{1} & \multicolumn{6}{|c|}{2} \\
\hline
\end{tabular}

\section{Ch. *Festuco-Brometea:}

*Coronilla varia

*Achillea collina

*Galium album

*Euphorbia cyparissias

* Medicago falcata

* Pimpinella saxifraga

*Euphrasia stricta

*Verbascum lychnitis

*Polygala comosa

\section{Ch. ${ }^{\circ}$ Molinio-Arrhenatheretea:}

*Festuca rubra

* Dactylis glomerata

* Knautia arvensis

*Arrhenatherum elatius

*Lotus corniculatus

*Trifolium pratense

* Taraxacum officinale

* Agrostis stolonifera

Accompanying species:

* Crataegus monogyna

* Rhamnus catharticus

* Rosa canina

* Pinus sylvestris

*Cornus sanguinea

*Linum catharticum

* Medicago lupulina

*Rubus caesius

* Fragaria vesca

*Hypericum perforatum

*Hieracium pilosella

*Veronica chamaedrys

*Senecio jacobaea

*Agropyron repens

*Daucus carota

*Trifolium arvense

* Carex hirta

* Melilotus officinalis

*Carex spicata 


\begin{tabular}{|c|c|c|c|c|c|c|c|c|c|c|c|c|}
\hline 11 & 12 & 13 & 14 & 15 & 16 & 17 & 18 & 19 & 20 & 21 & 22 & \\
\hline 15 & 12 & 16 & 24 & 17 & 18 & 11 & 21 & 22 & 23 & 25 & 14 & \\
\hline $\mathrm{Rz}$ & B & $\mathrm{Rz}$ & $\mathrm{Rz}$ & $\mathrm{Rz}$ & $\mathrm{Rz}$ & $\mathrm{P}$ & $\mathrm{P}$ & $\mathrm{P}$ & $\mathrm{Rz}$ & $\mathrm{Sm}$ & $\mathrm{Rz}$ & \\
\hline 27 & 2 & 27 & 4 & 27 & 27 & 2 & 4 & 4 & 4 & 4 & 27 & \\
\hline 8 & 8 & 8 & 8 & 8 & 8 & 8 & 8 & 8 & 8 & 7 & 8 & 8 \\
\hline 10 & 10 & 10 & 11 & 10 & 10 & 10 & 11 & 11 & 11 & 12 & 10 & $\vec{b}$ \\
\hline 50 & 50 & 50 & 50 & 50 & 50 & 50 & 40 & 50 & 40 & 30 & 50 & o \\
\hline SSE & NW & SSW & SSE & SW & SSW & SE & SSW & ENE & NNE & SSE & SW & ల \\
\hline 3 & 10 & 5 & 3 & 10 & 10 & 10 & 5 & 30 & 5 & 5 & 3 & ల్ల్ \\
\hline 5 & 5 & 5 & 20 & - & - & - & - & + & 20 & - & 10 & $=$ \\
\hline 100 & 100 & 95 & 100 & 100 & 100 & 100 & 100 & 100 & 100 & 100 & 95 & \\
\hline 30 & - & 20 & + & 10 & 5 & - & 5 & + & 20 & 5 & 20 & \\
\hline $\mathrm{f}$ & $\mathrm{g}$ & $\mathrm{f}$ & $\mathrm{g}$ & $\mathrm{g}$ & $\mathrm{g}$ & $\mathrm{g}$ & $\mathrm{g}$ & $\mathrm{g}$ & $\mathrm{g}$ & $\mathrm{g}$ & f & \\
\hline 42 & 40 & 44 & 48 & 37 & 36 & 35 & 41 & 36 & 45 & 36 & 51 & \\
\hline \multicolumn{13}{|c|}{3} \\
\hline 2 & 1 & 1 & + & 1 & 2 & 2 & 1 & 1 & + & 3 & 2 & $\mathrm{~V}$ \\
\hline 1 & . & 1 & + & 2 & 1 & 1 & 1 & 1 & + & + & + & $\mathrm{V}$ \\
\hline 1 & 1 & + & 1 & + & + & 1 & 2 & 2 & 2 & 2 & 1 & $\mathrm{~V}$ \\
\hline+ & . & 1 & + & . & 1 & 1 & 2 & . & + & + & 1 & IV \\
\hline+ & . & . & 2 & + & . & . & . & . & + & . & + & III \\
\hline . & + & . & . & . & . & 1 & 2 & 2 & + & . & . & II \\
\hline+ & . & + & . & + & . & . & . & . & . & . & . & II \\
\hline . & . & + & . & 1 & . & . & . & . & . & . & + & II \\
\hline . & . & + & + & . & . & . & + & . & + & . & . & II \\
\hline 2 & 1 & 1 & 2 & 2 & 2 & 2 & 1 & 2 & 2 & 2 & 1 & V \\
\hline+ & + & + & + & + & . & + & + & 1 & 1 & + & + & $\mathrm{V}$ \\
\hline . & 1 & + & + & + & + & + & + & 1 & . & + & + & $\mathrm{V}$ \\
\hline 2 & 1 & 1 & 1 & 1 & . & 1 & 2 & 2 & 2 & 1 & 2 & IV \\
\hline . & . & . & + & + & + & + & . & + & + & . & . & III \\
\hline+ & . & . & + & . & + & + & . & + & . & . & . & III \\
\hline . & + & + & . & . & . & + & . & . & + & . & $\mathrm{r}$ & III \\
\hline . & + & . & . & 2 & 1 & . & . & + & + & . & . & II \\
\hline $1+$ & $1+$ & . & . & . & $1+$ & . & . & +1 & . & . & $1+$ & II \\
\hline $1+$ & . & . & $1+$ & . & $1+$ & . & . & . & . & . & $1+$ & II \\
\hline I+ & 1/ & $1+$ & $1 /$ & . & . & . & . & . & . & $1+$ & $+/$ & II \\
\hline 1 & . & 1 & . & . & . & . & . & . & 1 & . & 1 & II \\
\hline . & . & . & $2 /+$ & . & $1+$ & . & . & . & $+/+$ & . & $1+$ & II \\
\hline . & . & + & 1 & . & + & . & . & . & + & . & 1 & III \\
\hline+ & . & . & + & . & . & . & . & . & + & . & + & II \\
\hline . & 2 & + & . & . & . & . & . & . & . & . & + & II \\
\hline . & 2 & . & . & . & . & . & 1 & . & 1 & . & 1 & II \\
\hline . & . & + & + & . & . & . & + & . & + & 1 & . & II \\
\hline+ & . & + & . & . & + & . & . & . & . & . & + & II \\
\hline . & . & . & . & + & . & 1 & + & 1 & + & . & . & II \\
\hline . & . & . & + & . & . & + & . & . & + & . & + & II \\
\hline . & . & . & . & . & . & + & . & + & + & . & . & II \\
\hline . & . & . & . & . & . & + & . & . & . & . & . & II \\
\hline+ & . & . & . & . & + & . & . & . & . & . & . & II \\
\hline . & + & . & . & 2 & 1 & . & 2 & . & . & . & . & II \\
\hline+ & . & + & . & . & . & + & . & . & . & . & 1 & II \\
\hline+ & . & . & + & . & . & + & + & . & . & . & . & II \\
\hline
\end{tabular}

Sporadic species: Ch. Festuco-Brometea: Acinos arvensis 6; Allium oleraceum 7, 9, 18, 22; Asperula cynanchica 4; Bromus inermis 6; Campanula glomerata 19; Carlina acaulis 4, 6; C. vulgaris 6, 9, 11; Erigeron acris 5, 8, 11; Fragaria viridis 13,14 (3), 21(1), 22(2); 
Helianthemum nummularium subsp. obscurum 4(1), 18, 21(1); Melampyrum arvense 1, 3, 10, 18(1); Peucedanum oreoselinum 4(1); Phleum phleoides 1(1), 4(1), 5, 7(1); Plantago media 10, 12, 14, 20; Potentilla heptaphylla 17, 18, 19; P. neumanniana 13, 22; Ranunculus bulbosus 10; Thalictrum minus 9, 17; Thymus glabrescens 21; Trifolium montanum 1, 4(1); Vicia tenuifolia 10, 12(3); Vincetoxicum hirundinaria 7 , 18, 21; Viola rupestris 13. Ch. Molinio-Arrhenatheretea: Centaurea jacea 12; Cerastium holosteoides 3, 13, 22; Crepis biennis 1, 2(1), 5, 8; Deschampsia caespitosa 12; Holcus lanatus 9; Lolium perenne 1; Pastinaca sativa 8, 10; Potentilla reptans 12; Prunella vulgaris 13; Tragopogon orientalis 12, 19; Trifolium repens 14, 15, 19, 21; Trisetum flavescens 21. Accompanying species: Acer platanoides 5 c, 14 c; A. pseudoplatanus 5 c; Aegopodium podagraria 12; Allium vineale 11, 17; Apera spica-venti 1, 2; Arenaria serpyllifolia 13, 22; Artemisia vulgaris 1(1), 2(1); Astragalus glycyphyllos 18; Botrychium lunaria 6; Calamagrostis epigejos 6(1); Campanula persicifolia 1, 2; C. rapunculoides 1, 2, 12; Carex flacca 12(1), 14; Carpinus betulus 13 c, 17 c; Chaerophyllum aromaticum 2(1); Cirsium arvense 2, 8; Clinopodium vulgare 14, 20; Corylus avellana 22 c; Cruciata glabra 18; Danthonia decumbens 16; Dianthus deltoides 9; Echium vulgare 9; Equisetum arvense 5, 11, 12, 22; Erigeron annuus 1, 9; Erysimum hieraciifolium 10; Euonymus europaeus 14c; Euphorbia esula 8, 12; Geum urbanum 5; Hieracium umbellatum 6; Hypochoeris radicata 9, Juniperus communis 20 b(2), c, 22 b; Linaria vulgaris 11; Lupinus polyphyllus 20; Medicago sativa 11; M. ×varia 2(2), 8,18(1), 22; Melandrium album 5, 8; Melilotus alba 18; Myosotis arvensis 1, 5; Orobanche lutea 4, Potentilla argentea 5, P. collina 12, 15; Primula veris 12; Pyrus communis 12 b, 20 b(1); Quercus robur 14 c, 16 c; Q. rubra 14 c; Rumex acetosella 6, 13; R. thyrsiflorus 1, 2(1); Sedum acre 6, 7, 11, 15; S. maximum 5, 7; S. sexangulare 15; Solidago canadensis 1, 2(1), 21, 22; S. virgaurea 14, 20(1), 22; Stellaria graminea 21; Trifolium campestre 16; T. medium 8, 21; Tussilago farfara 12, Valeriana officinalis 2; Vicia hirsuta 17, 20; V. tetrasperma 22.

Explanations: B - Bzów, O - Okradzionów, P - Podzamcze, Rz - Rzędkowice, S - Strzyżowice, Sł - Sławków, Sm - Smoleń; f - fallow land, g-xerothermic grassland, $\mathrm{r}$ - roadside 